\title{
VEGETATION OF HUMIC LAKES IN RELATION TO THEIR TROPHIC STATE
}

\author{
WOJCIECH EJANKOWSKI*, ANNA M. IGLIŃSKA
}

Department of Botany and Hydrobiology, Institute of Environment Protection, The John Paul II Catholic University of Lublin, Konstantynów 1H, 20-708 Lublin, Poland; e-mail: wejan@kul.lublin.pl

Chair of Geobotany and Landscape Planning, Nicolaus Copernicus University, Gagarina 9, 87-100 Toruń, Poland; e-mail: filipendula@wp.pl

*Author for correspondence

\begin{abstract}
Ejankowski W., Iglińska A.M.: Vegetation of humic lakes in relation to their trophic state. Ekológia (Bratislava), Vol. 33, No. 2, p. 160-170, 2014.

The vegetation of selected 24 humic lakes in Poland was studied to establish whether there was a link between the lakes' vegetation and their trophic state. Based on literature data and field studies, the lakes were distinguished into two groups with regard to plant communities in the lakes and catchment basins. They were identified as dystrophic (DL) and humoeutrophic (HL) lakes according to their chemical and biological parameters. The two lake groups differed in terms of macrophyte structure: nymphaeids were common in DL, whereas helophytes in HL. The massive development of elodeids was also observed in HL. Vegetation in the catchment basins was mesotrophic in HL (Caricion lasiocarpae Vanden Bergh. ap. Lebrun et al., 1949), whereas in case of extremely nutrient-poor habitats in DL oligotrophic vegetation was found (Rhynchosporion albae Koch 1926 and Oxycocco-Sphagnetea Br.-Bl. et. R.Tx. 1943). The regionally determined variability of humic lakes in Poland was verified positively. Potential dystrophy indicators are discussed in this paper.
\end{abstract}

Key words: macrophytes, aquatic vegetation, peat bogs, coloured lakes, natural habitats.

\section{Introduction}

Humic substances originating from catchment basins often influence lakes surrounded by peat bogs or situated in a peat bog-forest area. Especially, nutrient-poor raised bogs are very effective in terms of supplying water with humic acids (Górniak, 1996; Wojciechowski, 1999). Humic substances are the organic compounds that determine specific characteristics of water bodies and affect their functioning. The lakes rich in humic substances, called humic lakes, contain organic sediments and have yellow or yellow-brown coloured water with very low light availability for primary producers and usually a low water reaction (Hansen, 1962; Jones, 1992; Górniak, 1996).

Vegetation in the humic lakes is usually dominated by mosses and nymphaeids instead of elodeids and isoetids. There are floating peat mats with sedges (Cyperaceae) and mosses 
belonging to the genus Sphagnum Hedw. in the lake margins (Iversen, 1929; Piotrowicz et al., 2006). The zone of floating peat mats is followed by the zone of raised peat bogs, which is then followed by coniferous forests (Sobotka, 1967).

Humic substances cause dystrophication processes in water. They combine with simple nutrients make them into complex ones and affect the availability of these compounds for phytoplankton and aquatic macrophytes (Jones, 1992). Hence, the humic lakes are often characterised with low productivity and low biological diversity. They are called dystrophic (DL) due to high deficits of nutrients (Thienemann, 1921; Hansen, 1962).

However, the productivity of coloured lakes is generally as high as or even higher than that of clear water lakes, poor in humic substances. Even in different parts of the world, nutrients concentration is higher in humic lakes, where it often indicates a eutrophic state, than in clear water lakes (Nürnberg, Shaw, 1999; Gąbka, Owsianny, 2006; Poniewozik et al., 2011). Such waters have nearly a neutral or alkaline reaction and high phytoplankton biomass, even if they are surrounded by peat bogs and are rich in organic sediments (Owsianny, Gąbka, 2007).

Humic lakes rich in nutrients are determined as aloiotrophic (Höll, 1928), humoeutrophic (HL) (Górniak, 1996) or dystrophic-eutrophic (Fijałkowski, 1959), to emphasise their intermediate character between dystrophy and eutrophy. HL lakes were found in different regions such as North America, Germany and Poland (Juday, Birge, 1932; Ohle, 1934; Gąbka, Owsianny, 2006; Chmiel, 2009).

Some lakes are classified as a DL type due to peat bog vegetation in the catchment area, brown-coloured water and sediments, often regardless of their hydrochemical properties (Hansen, 1962; Owsianny and Gąbka, 2007). Nevertheless, the term 'dystrophic' should only be used with reference to the waters with prevailing dystrophication processes, poor in available nutrients, and not as a general term for all the humic ones (Górniak, 1996; Owsianny, Gąbka, 2007).

A catchment area is the major factor determining the quantity of humic compounds in lakes at a regional level (Kortelainen, 1993; Sobek et al., 2006). Especially, the proportion of peatlands in the catchment area can influence humic substances content in water (Kononova, 1961; Reinikainen, Hyvärinen, 1997). A high concentration of humic acids in relation to fulvic acids, both of them being humic compounds, results in stronger acidification. Thus, a relatively high content of humic acids in peat bogs in comparison to fens can lead to stronger dystrophication in lakes (Górniak, 1996; Reinikainen, Hyvärinen, 1997).

Development of peat bogs was reported as a diagnosis of the ecological state of a DL lake after an anthropogenic disturbance (Hutorowicz, 2001). Nevertheless, the occurrence of a floating peat mat as a sufficient indicator of hydrochemical dystrophication was questioned (Owsianny, Gąbka, 2007).

Hydrobiological and hydrochemical studies were also carried out in many of the lakes to find out the differences between them (Kraska et al., 2001; Chmiel, 2009; Poniewozik et al., 2011). Vegetation of many humic lakes has been extensively studied (Sugier, Popiołek, 1999; Piotrowicz et al., 2006; Sender, 2009), but detailed comparison of vegetation in strictly DL and HL lakes is lacking (Gąbka, Owsianny, 2006).

DL lakes are protected by Natura 2000 Networking Programme (IOŚ, 2010). The correct identification of natural habitats is important in order to support their effective protection. 
Because the identification is still problematic, simple indicators of these habitats are needed. The aim of this study was to show the variation of plant communities in humic lakes in relation to the trophic state and to identify indicators of DL lakes within the vegetation cover.

\section{Material and methods}

Vegetation of 18 humic lakes and 2 lake complexes (24 lakes in total) in different regions of Poland was compared in this study (Table 1). The majority of lakes were situated in Northern Poland in Bory Tucholskie, Brodnica Lake District, Drawno Plain, Garb Lubawski and in the mid-Eastern part of the country (Łęczna-Włodawa Plain). One complex was located in the Masurian Lake District in North-Eastern Poland (Kondracki, 2002).

T a b l e 1. Location of the studied humic lakes and data sources.

\begin{tabular}{|c|c|c|c|c|}
\hline No. & Name of lake & Region & Coordinates & Data sources \\
\hline 1 & Moszne & Łęczna-Włodawa Plain & $51^{\circ} 27^{\prime} 28^{\prime \prime} \mathrm{N}, 23^{\circ} 07^{\prime} 16^{\prime \prime} \mathrm{E}$ & Sender 2008, 2009; Lorens 2009 \\
\hline 2 & Długie & Łęczna-Włodawa Plain & $51^{\circ} 27^{\prime} 16^{\prime \prime} \mathrm{N}, 23^{\circ} 10^{\prime} 11^{\prime \prime E}$ & Sugier \& Popiołek 1999 \\
\hline 3 & Brzeziczno & Łęczna-Włodawa Plain & $51^{\circ} 23^{\prime} 04^{\prime \prime} \mathrm{N}, 23^{\circ} 00^{\prime} 32^{\prime \prime} \mathrm{E}$ & GDOŚ 2010, Sender 2009. \\
\hline 4 & Łokietka & Łęczna-Włodawa Plain & $51^{\circ} 23^{\prime} 45^{\prime \prime} \mathrm{N}, 22^{\circ} 57^{\prime} 36^{\prime \prime} \mathrm{E}$ & field studies \\
\hline 5 & Orchowo & Łęczna-Włodawa Plain & $51^{\circ} 29^{\prime} 25^{\prime \prime} \mathrm{N}, 23^{\circ} 34^{\prime} 26^{\prime \prime} \mathrm{E}$ & Urban 2001, Sender 2009 \\
\hline 6 & Rogoźne & Łęczna-Włodawa Plain & $51^{\circ} 30^{\prime} 35^{\prime \prime} \mathrm{N}, 23^{\circ} 31^{\prime} 01^{\prime \prime E}$ & Lorens 2009, Sender 2009 \\
\hline 7 & Obradowskie & Łęczna-Włodawa Plain & $51^{\circ} 35^{\prime} 19^{\prime \prime} \mathrm{N}, 22^{\circ} 52^{\prime} 30^{\prime \prime} \mathrm{E}$ & Karczmarz \& Sokołowski 1988 \\
\hline 8 & Kaczewo & Bory Tucholskie & $53^{\circ} 54^{\prime} 59^{\prime \prime} \mathrm{N}, 17^{\circ} 33^{\prime} 33^{\prime \prime} \mathrm{E}$ & $\begin{array}{l}\text { Rejewski 1981, } \\
\text { Boińska \& Boiński } 1993\end{array}$ \\
\hline 9 & Piecki Małe & Bory Tucholskie & $53^{\circ} 54^{\prime} 54^{\prime \prime} \mathrm{N}, 17^{\circ} 34^{\prime} 06^{\prime \prime} \mathrm{E}$ & $\begin{array}{l}\text { Rejewski 1981, } \\
\text { Boińska \& Boiński } 1993 \\
\end{array}$ \\
\hline 10 & Dystrof I & Bory Tucholskie & $53^{\circ} 54^{\prime} 35^{\prime \prime} \mathrm{N}, 17^{\circ} 33^{\prime} 38^{\prime \prime} \mathrm{E}$ & Boińska \& Boiński 1993 \\
\hline 11 & Dystrof II & Bory Tucholskie & $53^{\circ} 54^{\prime} 54^{\prime \prime} \mathrm{N}, 17^{\circ} 33^{\prime} 18^{\prime \prime} \mathrm{E}$ & Boińska \& Boiński 1993 \\
\hline 12 & Okonek & Brodnica Lake District & $53^{\circ} 23^{\prime} 08^{\prime \prime N}, 19^{\circ} 24^{\prime} 25^{\prime \prime} \mathrm{E}$ & Paszek \& al. 2011a \\
\hline 13 & Stręszek & Brodnica Lake District & $53^{\circ} 22^{\prime} 57^{\prime \prime} \mathrm{N}, 19^{\circ} 23^{\prime} 52^{\prime \prime} \mathrm{E}$ & Paszek \& al. 2011b \\
\hline 14 & Kociołek & Brodnica Lake District & $53^{\circ} 29^{\prime} 31^{\prime \prime N}, 19^{\circ} 24^{\prime} 26^{\prime \prime} \mathrm{E}$ & Załuski 1996 \\
\hline 15 & Głodne Jeziorka II & Drawno Plain & $53^{\circ} 11^{\prime} 37^{\prime \prime} \mathrm{N}, 16^{\circ} 4^{\prime} 5^{\prime \prime} \mathrm{E}$ & $\begin{array}{l}\text { Kraska et al. 2001, } \\
\text { Piotrowicz et al. } 2006\end{array}$ \\
\hline 16 & Głodne Jeziorka III, V & Drawno Plain & $\begin{array}{l}53^{\circ} 11^{\prime} 36^{\prime \prime} \mathrm{N}, 16^{\circ} 4^{\prime} 20^{\prime \prime} \mathrm{E} \\
53^{\circ} 11^{\prime} 39^{\prime \prime} \mathrm{N}, 16^{\circ} 4^{\prime} 33^{\prime \prime} \mathrm{E} \\
\end{array}$ & $\begin{array}{l}\text { Kraska et al. 2001, } \\
\text { Piotrowicz et al. } 2006\end{array}$ \\
\hline 17 & Piaseczno Małe & Drawno Plain & $53^{\circ} 7^{\prime} 21^{\prime \prime N}, 15^{\circ} 59^{\prime} 49^{\prime \prime} \mathrm{E}$ & Piotrowicz et al. 2006 \\
\hline 18 & Bagno Jeleńskie I & Garb Lubawski & $53^{\circ} 18^{\prime} 4^{\prime \prime N}, 19^{\circ} 52^{\prime} 21^{\prime \prime E}$ & field studies \\
\hline 19 & Bagno Jeleńskie II & Garb Lubawski & $53^{\circ} 18^{\prime} 4^{\prime \prime N}, 19^{\circ} 52^{\prime} 42^{\prime \prime E}$ & field studies \\
\hline 20 & Bagno Jeleńskie III & Garb Lubawski & $53^{\circ} 17^{\prime} 59^{\prime \prime} \mathrm{N}, 19^{\circ} 53^{\prime} 16^{\prime \prime} \mathrm{E}$ & field studies \\
\hline 21 & Zakręt & Masurian Lake District & $\begin{array}{l}53^{\circ} 41^{\prime} 3^{\prime \prime} \mathrm{N}, 21^{\circ} 24^{\prime} 54^{\prime \prime} \mathrm{E} \\
53^{\circ} 41^{\prime} 1^{\prime \prime} \mathrm{N}, 21^{\circ} 24^{\prime} 40^{\prime \prime} \mathrm{E} \\
53^{\circ} 41^{\prime} 15^{\prime \prime} \mathrm{N}, 21^{\circ} 24^{\prime} 40^{\prime \prime} \mathrm{E}\end{array}$ & field studies \\
\hline
\end{tabular}

The lakes chosen in this study were the humic lakes determined as DL, HL or dystrophic-eutrophic according to the following heterogeneous criteria: hydrochemical, hydrobiological or floristic (literature cited in Table 1). Lake Rogoźne had formerly been characterised as dystrophic-eutrophic (Fijałkowski, 1959), but currently it has been identified as eutrophic (Wojciechowska, Solis, 2009).

Data were collected from literature sources and field studies carried out between 2002 and 2011. Numerical data, vegetation maps and detailed descriptions of the plant cover in humic lakes were used in the analysis. Aquatic vegetation and open peat bogs in the catchment basins of the lakes were included. During the fieldwork a percentage 
share of particular plant communities was determined. The identification of plant associations was performed after a vegetation survey in the field supported by an analysis of aerial photographs. Only the plant communities that exceeded $10 \%$ of cover in a lake or in a peat bog were included to make a data set comparable.

A classification system of vegetation according to the phytosociological method of Braun-Blanquet (1951) was used. Syntaxonomy and nomenclature of plant communities followed Matuszkiewicz (2001) and Brzeg and Wojterska (2001) guidelines.

Submerged aquatic vegetation (SAV) in the lakes was compared using a rating scale proposed by Bayley and Prather (2003). The following five rank categories were defined: (1) no plant cover observed, (2) rare plant cover $(<5 \%),(3)$ occasional plant cover (5-25\%), (4) common plant cover (25-75\%) and (5) abundant plant cover (>75\%). A cluster analysis based on the composition of plant communities was used to classify the lakes into different groups.

The classification was carried out with unweighted pair group method with arithmetic mean (UPGMA) method with binomial Jaccard's coefficient as a similarity measure (Kovach, 1986-1999). As the data did not meet assumptions of a parametric analysis, a non-parametric Mann-Whitney test was used to evaluate a regional variability of lakes and the bioindicator value of vegetation. All the calculations were performed with MVSP ver. 3.1 and Statistica 9.1 according to Sokal and Rohlf (1995).

\section{Results}

Different ecological groups of macrophytes, elodeids, nymphaeids and helophytes were observed in humic lakes. Peat bogs surrounded almost all the water bodies, which was in agreement with usually observed high concentration of humic substances. The vegetation that dominated in the lakes comprised of six phytosociological groups of different ranks. Not only plant communities typical of nutrient-poor habitats, but also vegetation dependent on eutrophic conditions was found (Table 2).

T a bl e 2. Plant communities dominating humic lakes.

\begin{tabular}{|l|l|}
\hline Vegetation type & Plant communities \\
\hline $\begin{array}{l}\text { Potamion Koch } 1926 \text { em. Oberd. 1957 } \\
\text { (all.) }\end{array}$ & Myriophylletum spicati Soe 1927, \\
\hline Nymphaeion Oberd. 1953 (all.) & $\begin{array}{l}\text { Nupharo-Nymphaeetum albae Tomasz. 1977, Nymphaeetum can- } \\
\text { didae Miljan 1958, Potametum natantis Soó 1923, }\end{array}$ \\
\hline Phragmitetea R.Tx. et Prsg 1942 (cl.) & $\begin{array}{l}\text { Phragmitetum australis (Gams 1927) Schmale 1939, Typhetum la- } \\
\text { tifoliae Soó 1927, T. angustifoliae (Allorge 1922) Soó 1927, Carice- } \\
\text { tum rostratae Rübel 1912, Equisetetum fluviatilis Steffen 1931, Ele- } \\
\text { ocharitetum palustris Šennikov 1919, Scirpetum lacustris (Allorge } \\
\text { 1922) Chouard 1924, Caricetum acutiformis Sauer 1937, Thelypte- } \\
\text { ridi-Phragmitetum Kuiper 1957, Cicuto-Caricetum pseudocyperi } \\
\text { Boer et Siss. in Boer 1942, }\end{array}$ \\
\hline $\begin{array}{l}\text { Caricion lasiocarpae Vanden Bergh. ap. } \\
\text { Lebrun et all. 1949 (all.) }\end{array}$ & $\begin{array}{l}\text { Caricetum lasiocarpae Koch 1926, Sphagno apiculati-Caricetum } \\
\text { rostratae Osvald 1923, }\end{array}$ \\
\hline Rhynchosporion albae Koch 1926 (all.) & Rhynchosporetum albae Koch 1926, Caricetum limosae Br.-Bl. 1921, \\
\hline $\begin{array}{l}\text { Oxycocco-Sphagnetea Br. Bl. et R.Tx. } \\
1943 \text { (cl.) }\end{array}$ & $\begin{array}{l}\text { Sphagnetum magellanici (Malc. 1929) Kästner et Flössner 1933, } \\
\text { Ledo-Sphagnetum magellanici Sukopp 1959 em. Neuhäusl 1969 }\end{array}$ \\
\hline
\end{tabular}

Explanations: all. - alliance, cl. - class.

SAV belonging to the alliance Potamion constituted the vegetation in 2 lakes out of the total 24. Despite the fact that submerged macrophytes occur occasionally in humic lakes, in this particular case the development of Myriophyllum spicatum L. was massive. Associations of Nymphaea alba L., N. candida C. Presl and Nuphar lutea (L.) Sibth. et Sm. formed nym- 
phaeids belonging to the alliance Nymphaeion. They were common, but they were rarely numerous in lakes. Another group of macrophytes, helophytes from the class Phragmitetea, was differentiated and abundant in the lake margins. Associations of Phragmites australis (Cav.) Trin. ex Steud. were the most frequent plant communities in this group. The vegetation of floating peat mats and peat bog hollows belonging to the class Scheuchzerio-Caricetea nigrae. Plant communities from the two ecologically different alliances Rhynchosporion albae and Caricion lasiocarpae were reported in this study (Table 2). The vegetation of raised peat bogs was classified to the class of Oxycocco-Sphagnetea.

The cluster analysis showed differences among lakes with regard to vegetation. Lake Rogoźne was distinct due to a scarce development of peat bog vegetation and the dominance of helophytes in the water body; the presence of association Cicuto-Caricetum pseudocyperi was specific to this lake (Fig. 1). Low Jaccard's coefficient (0.03) indicated a low degree of similarity between the vegetation of Lake Rogoźne and that of other lakes in the clustering diagram (Fig. 1).

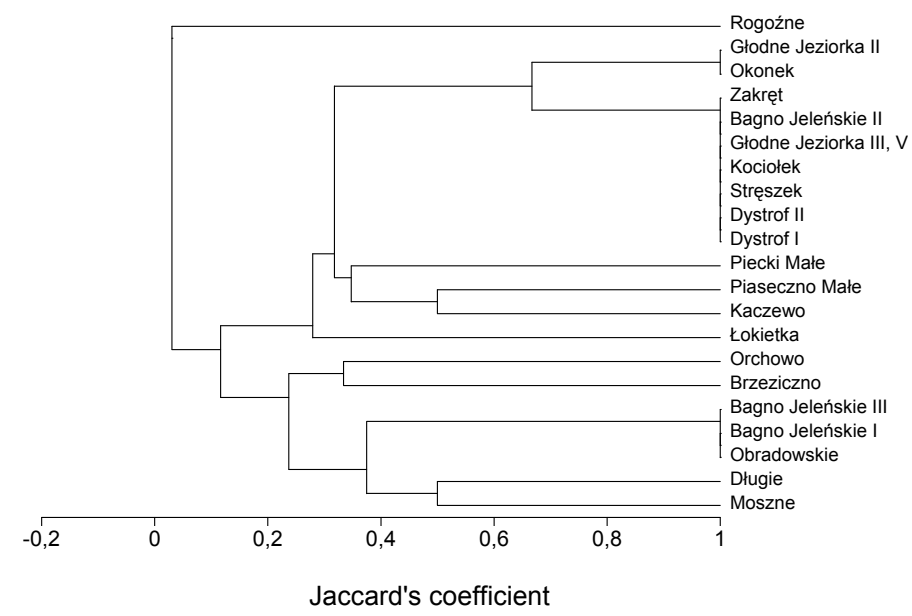

Fig. 1. Cluster analysis of vegetation in humic lakes.

A floristically homogenous group of lakes was distinguished using Jaccard's coefficient's value of 0.32. Group I comprised of the following lakes: Głodne Jeziorka II, Okonek, Zakręt, Bagno Jeleńskie II, Głodne Jeziorka III and V, Kociołek, Stręszek, Dystrof II and Dystrof I, Piecki Małe, Piaseczno Małe and Kaczewo. Aquatic vegetation in this group was usually of small importance and no submerged macrophytes occurred in these lakes. Mainly plant communities of the alliance Rhynchosporion albae and the class Oxycocco-Sphagnetea dominated in group I. The separation of the lakes Piecki Małe, Piaseczno Małe and Kaczewo within this cluster was caused by a high development of nymphaeids and helophytes. The following plant communities: NupharoNymphaetum albae, Potametum natantis, Equisetetum limosi and Caricetum acutiformis were the dominants in the water bodies mentioned above, whereas these plant associations barely occurred in the other lakes of group I. 
The remaining lakes Łokietka, Orchowo, Brzeziczno, Bagno Jeleńskie III and I, Obradowskie, Długie and Moszne constituted group II (Fig. 1). In spite of differences among them, the vegetation of these lakes usually comprised of plant communities of the class Phragmitetea and the alliance Caricion lasiocarpae. The most frequent Phragmitetea-associations were here Phragmitetum communis, Typhaeetum latifoliae and Typhaeetum angustifoliae. In this group, plant associations of the class Oxycocco-Sphagnetea were lacking, except for Lake Łokietka, which was floristically similar to the lakes of group I (Fig. 1). In this lake, only co-domination of Phragmitetum communis determined its separation from group I. The two water bodies, Lake Moszne and Lake Długie, were distinguished from the other lakes in group II because of the development of submerged macrophyte M. spicatum.

Vegetation cover in the humic lakes was regionally differentiated. It was noticeable that the lakes of group I were situated in the regions of Northern Poland, whereas the lakes of group II were mainly located within the mid-Eastern part of the country $(U=-2.44, p<0.05)$. Only two lakes belonging to group II (Bagno Jeleńskie I and II) were located in Northern Poland in the Garb Lubawski region. However, due to the differences in vegetation, the lakes situated in the lake-peat bog complex Bagno Jeleńskie were classified into two different groups. Lake Bagno Jeleńskie II was included in group I, whereas the lakes Bagno Jeleńskie I and III joined group II (Fig. 1).

The vegetation composition of analysed water bodies was affected by trophic conditions. Frequency of plant communities typical of nutrient-poor habitats (Rhynchosporion albae and Oxycocco-Sphagnetea) was higher in group I than in group II. Similarly, nymphaeids (Nymphaeion) commonly occurred only in the lakes of group II (Fig. 2). Associations dependent on moderately fertile bogs (Caricion lasiocarpae) and vegetation of eutrophic habitats (Phragmitetea) were usually found in the lakes of group II.

No significant statistical effects were found in particular plant communities belonging to the class Phragmitetea and to the alliance Nymphaeion, despite the fact that such effects of total Phragmitetea and total Nymphaeion were important (Table 3). Probably more data were needed

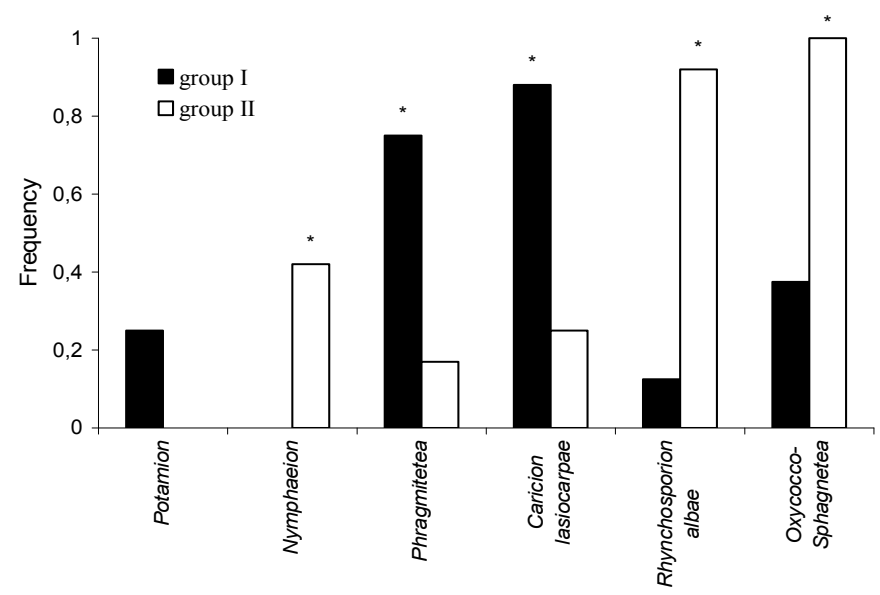

Fig. 2. Vegetation dominating in different trophic types of humic lakes (explanation: asterisks sign important effects). 
to reveal the significant relationships between the discussed phenomena, because many plant communities occurred occasionally in the investigated water bodies.

The index of SAV was 1 in the lakes of group I and on average 1.75 in group II. A plant association Myriophylletum spicati occurred only in the lakes of group II (Fig. 2), with the maximum cover in Lake Moszne (58.4\%). However, no significant relationship was found between elodeids (total Potamion) and the lake type distinguished in this study (Table 3).

T a ble 3. Mann-Whitney tests of relationships between vegetation and groups of humic lakes distinguished in the study.

\begin{tabular}{|l|c|c|c|c|}
\hline Vegetation & Sum of ranks group I & Sum of ranks group II & N & Z \\
\hline Caricetum acutiformis & 130 & 80 & 20 & -0.71 \\
\hline Caricetum rostratae & 126 & 84 & 20 & 0.04 \\
\hline Caricion lasiocarpae & 96 & 114 & 20 & $2.62^{* *}$ \\
\hline Cicuto-Caricetum pseudocyperi & 126 & 84 & 20 & -0.04 \\
\hline Eleocharitetum palustris & 130 & 80 & 20 & -0.71 \\
\hline Equisetetum fluviatilis & 130 & 80 & 20 & -0.71 \\
\hline Myriophylletum spicati & 114 & 96 & 20 & 1.71 \\
\hline Nymphaeetum candidae & 130 & 80 & 20 & -0.71 \\
\hline Nupharo-Nymphaeetum albae & 142 & 68 & 20 & -1.72 \\
\hline Oxycocco-Sphagnetea & 156 & 54 & 20 & $-3.03^{* *}$ \\
\hline Phragmitetum australis & 114 & 96 & 20 & 1.71 \\
\hline Potametum natantis & 134 & 76 & 20 & -1.11 \\
\hline Rhynchosporion albae & 164 & 46 & 20 & $-3.4^{* * *}$ \\
\hline Scirpetum lacustris & 120 & 90 & 20 & 1.12 \\
\hline Thelypteridi-Phragmitetum & 126 & 84 & 20 & 0.04 \\
\hline Thyphaetum angustifoliae & 114 & 96 & 20 & 1.71 \\
\hline Thyphaetum latifoliae & 120 & 90 & 20 & 1,12 \\
\hline Total Potamion & 114 & 96 & 20 & 1.71 \\
\hline Total Nymphaeion & 146 & 64 & 20 & $-2^{*}$ \\
\hline Total Phragmitetea & 98 & 112 & 20 & $2.50^{*}$ \\
\hline
\end{tabular}

Explanations: ${ }^{*} \mathrm{p}<0.05,{ }^{* *} \mathrm{p}<0.01,{ }^{* * *} \mathrm{p}<0.001, \mathrm{~N}-$ number of cases, $\mathrm{Z}$ - value of Mann-Whitney test.

\section{Discussion}

Results of this study suggest that main differences between the humic lakes were induced by trophy. Ecological requirements of the plant communities indicated nutrient-poor state in the lakes of group I and a moderately nutrient-rich state in group II. Especially, the vegetation belonging to Rhynchosporion albae and Oxycocco-Sphagnetea was associated with oligotrophic habitats, whereas that of Caricion lasiocarpae- and Phragmitetea-associations indicated habitats with higher trophy (Kłosowski, 1985; Rodwell, 1991; Matuszkiewicz, 2001).

This conclusion is supported by the studies of physical-chemical parameters of water. Reaction, calcium content and conductivity were considerably lower in group I lakes Głodne Jeziorka II, III, V and Piaseczno Małe than in Lake Moszne, Lake Długie and Lake Orchowo of group II (Kraska et al., 2001; Piotrowicz et al., 2006; Poniewozik et al., 2011). Within the lakes of group I 
parameters such as electrolytic conductivity, $\mathrm{pH}$ and chlorophyll-a were higher in Lake Piaseczno Małe, where Caricion lasiocarpae-associations were abundant (Piotrowicz et al., 2006). In many lakes of group II physical-chemical and biological parameters revealed an eutrophication process, despite the fact that the water was rich in humic substances (Wojciechowska, Solis, 2009; Poniewozik et al., 2011).

Hydrochemical dystrophic index (HDI) proposed by Górniak (2006) also provides information about the degree of dystrophy in lakes. It takes into consideration factors such as water reaction, electrolytic conductivity and concentration of organic carbon in water. This index was calculated for the lakes belonging to group II in the Łęczna-Włodawa Plain, where its value was usually below the limit of dystrophy (Chmiel, 2009), e.g. HDI in Lake Moszne and Lake Długie indicated a humoeutrophic state (Górniak, 1996, 2006). The highest values in this region were between 25 and 50. The assumptions of hydrochemical dystrophy were occasionally met in the lakes which were similar to group I with regard to the vegetation cover (Chmiel, 2009; Górniak, 2006). In strictly DL lakes in North-Eastern Poland and in several lakes in the Bory Tucholskie region HDI was above 50. In many lakes of Scandinavia the index of dystrophy was even higher.

Many observations confirm that lakes can be fertile in spite of the presence of humic substances in water (Hansen, 1962; Wojciechowski, 1999). We speculated that the lakes in group I reflected a DL type and at least most of lakes in group II, if not all of them, were HL. In this approach, dystrophy was determined as a polihumic and nutrient-poor state, whereas humoeutrophy was defined as relatively high trophy of the humic lake (Górniak, 1996).

Lake Rogoźne, which was separated from the other lakes in the cluster analysis, was determined as eutrophic according to hydrochemical and hydrobiological criteria (Chmiel, 2009; Wojciechowska and Solis, 2009). The helophytes in the lake margins and lack of peat bogs in the catchment basin corresponded with relatively high water trophy (Kłosowski, 1985; Matuszkiewicz, 2001).

Although the occurrence of peat bogs in the catchment area only presumably allows to indicate a DL lake type (Owsianny, Gąbka, 2007), it seems that vegetation can show the ecological state of a lake to a higher degree. It was found that the effect of dystrophication was stronger in the lakes surrounded by mires. Fens, which are more fertile, have a significantly lower impact on dystrophication than raised peat bogs (Kononova, 1961; Górniak, 1996; Wojciechowski, 1999).

The study has shown that the strict domination of Rhynchsporion albae- and OxycoccoSphagnetea-associations over other vegetation points to nutrient-poor DL lakes, in accordance to former observations of the ecological preferences of plant communities (Rodwell, 1991; Matuszkiewicz, 2001; Gąbka et al., 2007). High development of Caricion lasiocarpae-associations and helophytes (Phragmitetea) indicates HL state according to Górniak (1996).

Dystrophication takes place when the quantity of humic substances is considerably higher than the nutrients supply (Wojciechowski, 1999). When the quantity of humic substances is low, nutrients stimulate the growth of aquatic vegetation. Hence, SAV, which is associated with fertile habitats (Matuszkiewicz, 2001), was found only in HL lakes. High light availability due to low light attenuation facilitates the development of macrophytes under the water surface. Other aquatic plants, nymphaeids, were associated with DL lakes. Their higher abundance in DL waters, in comparison to eutrophic ones, was observed (Piotrowicz et al., 2006). Aquatic macrophytes can play an important role depending on their abundance and species composition. They can influence 
the functioning of water bodies in different ways. In shallow lakes, macrophytes stabilise the clear water state (Scheffer et al., 1993).

In this study the majority of humic lakes in the Łęczna-Włodawa Plain were identified as HL. Their intermediate character was also recognised in an assessment of natural habitats in Natura 2000 Networking Programme. The ecological state of the lakes in which the values of HDI were the highest in the region was analysed (Chmiel, 2009; IOS, 2010). Measurements of dystrophy such as water colour, phytoplankton, presence of expansive species, turbidity and state of peat bogs associated with the vegetation cover were usually evaluated negatively. The state between dystrophy and eutrophy observed in these lakes still makes their classification controversial (Pęczuła, 2002; Poniewozik et al., 2011), similarly to other regions (Gąbka, Owsianny, 2006; Owsianny, Gąbka, 2007).

We speculate that differences between the HL lakes in mid-Eastern Poland and strictly DL lakes in the rest of the country were caused by their geological structure and, consequently, the vegetation cover that affects humic substances in water. DL lakes mostly occur in crystal and sandy basins (Hansen, 1962; Rejewski, 1984; Owsianny, Gąbka, 2007). Sandy plains and dunes provide favourable conditions for the development of coniferous forests and nutrient-poor raised bogs (Matuszkiewicz, 2001), which influences acidification and dystrophication very effectively.

In the Łęczna-Włodawa Plain, which was ice-free during the Weichsel (Vistulian) glaciation, the geological structure and vegetation in the catchment basins are different. In this region, cretaceous sediments of large thickness occur under the superficial layer of aqueous rocks. Therefore, the basin can contribute to a relatively high concentration of calcium and nearly neutral water reaction (Wiszniewski, 1953; Harasimiuk, Wojtanowicz, 1998). Higher reaction caused by calcium content makes complexes of nutrients and humic substances instable and contributes to eutrophication (Górniak, 1996).

On the other hand, human activity can affect humic lakes too. Heterogeneity of vegetation within the complex Bagno Jeleńskie was seemingly induced by an anthropogenic impact. High development of Caricion lasiocarpae-association (Sphagno-Caricetum rostratae) in the lakes Bagno Jeleńskie I and III was probably caused by the transformations of hydrologic and trophic conditions. Plant communities of this type often occur in slightly enriched, soligenous areas (Rodwell, 1991; Gąbka et al., 2007). In this case, water was polluted and catchment basin was desiccated by drainage system. No detailed data are available on the nutrient content, but there was no obvious impact on Lake Bagno Jeleńskie II and the vegetation cover thereof was dependent on DL habitats (Matuszkiewicz, 2001).

\section{Conclusion}

Differences between the vegetation in the lakes rich in humic substances and in their catchment basins are induced by the trophic state. In the HL lakes in nutrient-limited habitats, plant communities are mostly mesotrophic, whereas in DL lakes vegetation is oligotrophic. Extremely nutrient-poor habitats of DL lakes are indicated by the dominance of nymphaeids (Nymphaeion) and plant communities belonging to the alliance Rhynchosporion albae and to the class Oxycocco-Sphagnetea. Indicators of the HL lakes are Caricion lasiocarpae- and Phragmitetea-associations. 


\section{References}

Bayley, S.E. \& Prather C.M. (2003). Do wetland lakes exhibit alternative stable states? Submersed aquatic vegetation and chlorophyll in western boreal shallow lakes. Limnol. Oceanogr., 48, 2335-2345. DOI: 10.4319/lo.2003.48.6.2335

Boińska, U. \& Boiński M. (1993). Vegetation of the nature reserve "Piecki" (in Polish). Acta Univ. Nicolai Copernici, 44, 123-143.

Braun-Blanquet, J. (1951). Phytosociology (in German). Wien: Springer Verlag.

Brzeg, A. \& Wojterska M. (2001). Vegetation of the Wielkopolska region, their state of knowledge and vulnerability (in Polish). In M. Wojterska (Ed.), Plant cover of the Wielkopolska region and South-Pomeranian Lake District (pp. 39110). Poznań: Bogucki Wyd. Nauk.

Chmiel, S. (2009). Hydrochemical evaluation of dystrophy of the water bodies in the Łęczna and Włodawa area in the years 2000-2008. Limnological Review, 9, 153-158.

Fijałkowski, D. (1959). Plant associations of lakes situated between Łęczna and Włodawa and of peat-bogs adjacent to these lakes (in Polish). Annales UMCS, sec. B, 14, 131-204.

Gąbka, M. \& Owsianny P.M. (2006). Shallow humic lakes of the Wielkopolska region - relation between dystrophy and eutrophy in lakes ecosystems. Limnological Review, 6, 95-102.

Gąbka, M, Owsianny, P.M. \& Sobczyński T. (2007). Comparison of the habitat conditions of peat-moss phytocoenoses dominated by Eriophorum angustifolium Honck. or Carex rostrata Stokes from mires in Western Poland. Biodiversity: Research and Conservation, 5-8, 61-69.

GDOŚ (Generalna Dyrekcja Ochrony Środowiska) (2010). Data base of the European Ecological Natura 2000 Network. - Data available at http://natura2000.gdos.gov.pl/natura2000/. Accessed January 2012.

Górniak, A. (1996). Humic substances and their role in functioning of freshwater ecosystems (in Polish). Dissertationes Universitatis Varsoviensis, Białystok.

Górniak, A. (Ed.) (2006). The lakes of the Wigry National Park. The current quality and trophy of waters (in Polish). Białystok: Wydawnictwo Uniwersytetu w Białymstoku.

Hansen, K. (1962). Dystrophic lake type. Hydrobiologia, 19, 183-190. DOI: 10.1007/BF00146361.

Harasimiuk, M. \& Wojtanowicz J. (1998). Geological structure and relief of the Łęczna-Włodawa Lake District (in Polish). In M. Harasimiuk, Z. Michalczyk \& M. Turczyński(Eds.), Lakes of Łęczna-Włodawa region. Nature monograph (pp. 41-53). Lublin: Biblioteka Monitoringu Środowiska.

Höll, K. (1928). Ecology of the Peridiniales (in Germany). Pflanzenforschung, 11, 1-105.

Hutorowicz, A. (2001). Phytoplankton of the humic lake Smolak against a background physico-chemical changes caused by liming and fertilization (in Polish). Idee Ekologiczne, 14(7).

IOŚ (Instytut Ochrony Środowiska) (2010). Monitoring of plant species and nature habitats with taking Natura 2000 special areas of conservation under consideration. Data available at http://www.iop.krakow.pl/cn2000/Monitoring/. Accessed January 2012.

Iversen, J. (1929). Study of pH-conditions of Danish waters and their influence on aquatic vegetation (in German). Botanisk Tiddskrift, 40, 277-333.

Jones, R.I. (1992). The influence of humic substances on lacustrine food chains. Hydrobiologia, 229, 73-91. DOI: 10.1007/ BF00006992.

Juday, C. \& Birge E.A. (1932). Dissolved oxygen and oxygen consumed in the lake waters of Northeastern Wisconsin. Trans. Wis. Acad. Sci., 27, 415-485.

Karczmarz, K. \& Sokołowski A.W. (1988). Peat-bog vegetation of the nature reserve Lake Obradowskie in the Łęczna and Włodawa Lake District (in Polish). Ann. UMCS, sec. C, 43, 103-117.

Kłosowski, S. (1985). Habitat conditions and bioindicator value of the main communities of aquatic vegetation in northeast Poland. Pol. Arch. Hydrobiol., 32, 7-29.

Kondracki, J. (2002). Geography of Polish regions (in Polish). Warszawa: Wyd. Nauk. PWN.

Kononova, M.M. (1961). Soil organic matter. Oxford: Pergamon Press.

Kortelainen, P. (1993). Content of total organic carbon in Finnish lakes and its relationship to catchment characteristics. Can. J. Fish. Aquat. Sci., 50, 1477-1483. DOI: 10.1139/f93-168.

Kovach, W. (1986-1999). Multi-Variate Statistical Package, ver. 3.1. Pentraeth.

Kraska, M., Borysiak, J., Danielak, K., Domek, P., Gołdyn, R., Joniak, T., Klimaszyk, P., Kujawa-Pawlaczyk, J., Piotrowicz, R., Radziszewska, R., Romanowicz, W., Szeląg-Wasilewska, E. \& Szyper H. (2001). Dystrophic lakes and meromictic lake in Drawa National Park (in Polish). In Plant cover of the Wielkopolska region and South-Pomeranian Lake District (pp. 371-400). Poznań: Bogucki Wyd. Nauk. 
Lorens, B. (2009). Analysis of successional changes in plant communities and flora of selected peat bogs in 1960-2009. In T.J. Chmielewski (Ed.), Ecology of hydrogenic landscapes in biosphere reserve "Polesie Zachodnie" (pp. 191-206). Lublin.

Matuszkiewicz, W. (2001). Guidebook for determination of plant communities in Poland (in Polish). Warszawa: Wyd. Nauk. PWN.

Nürnberg, G.K. \& Shaw M. (1999). Productivity of clear and humic lakes: nutrients, phytoplankton, bacteria. Hydrobiologia, 382, 97-112. DOI: 10.1023/A:1003445406964.

Ohle, W. (1934). The study of chemical and physical properties of lakes in Northern Germany (in German). Arch. Hydrobiol., 26, 386-653.

Owsianny, P.M. \& Gąbka M. (2007). Characeae- and dystrophic waters - identification features in the light of Natura 2000 Program and some cases from the Pilskie forests. Stud. Mat. CEPL, 2/3, 584-600.

Paszek, I., Iglińska, A., Kubiak-Wójcicka, K., Kołybski, W., Ładziński, R., Kosowicz, M. \& Koziński G. (2011a). Nature reserve "Okonek". Kujawsko-pomorskie Province, Brodnica District, Zbiczno Municipality. Protection plan for the period 1.01.2012-31.12.2031. Bydgoszcz: "Vitis” Iwona Paszek.

Paszek, I., Iglińska, A., Kubiak-Wójcicka, K., Kołybski, W., Ładziński, R., Kosowicz, M. \& Koziński G. (2011b). Nature reserve "Stręszek". Kujawsko-pomorskie Province, Brodnica District, Zbiczno Municipality. Protection plan for the period 1.01.2012-31.12.2031. Bydgoszcz: "Vitis" Iwona Paszek.

Pęczuła, W. (2002). Lake Płotycze - between eutrophy and dystrophy (about difficulties in obtaining trophic status of some lakes). Limnological Review, 2, 303-311.

Piotrowicz, R., Kraska, M., Klimaszyk, P., Szyper, H. \& Joniak T. (2006). Vegetation richness and nutrient loads in 16 lakes of Drawieński National Park (Northern Poland). Pol. J. Environ. Stud., 15, 467-478.

Poniewozik, M., Wojciechowska, W. \& Solis M. (2011). Dystrophy or eutrophy: phytoplankton and physicochemical parameters in the functioning of humic lakes. Oceanological and Hydrobiological Studies, 40, 22-29. DOI: 10.2478/ s13545-011-0013-8.

Reinikainen, J. \& Hyvärinen H. (1997). Humic- and fulvic-acid stratigraphy of the Holocene sediments from a small lake in Finnish Lapland. The Holocene, 7, 401-407. DOI: 10.1177/095968369700700403.

Rejewski, M. (1981). Vegetation of lakes near Laska in the Bory Tucholskie region (in Polish). Toruń: Uniwersytet Mikołaja Kopernika.

Rodwell, J.S. (Ed.) (1991). British plant communities. Mires and heaths. Cambridge University Press.

Scheffer, M., Hosper, S.H., Meijer, M.L., Moss, B. \& Jeppesen E. (1993). Alternative equilibria in shallow lakes. Trends Ecol. Evol., 8, 275-279.

Sender, J. (2008). Long term changes of macrophytes structure in the lake Moszne (Poleski National Park). Teka Kom. Ochr. Kszt. Środ. Przyr., 5, 154-163.

Sender, J. (2009). Analysis of successional changes in aquatic plant communities and macrophyte flora of selected lakes in 1960-2009. In T.J. Chmielewski (Ed.), Ecology of hydrogenic landscapes in biosphere reserve "Polesie Zachodnie" (pp. 161-190). Lublin.

Sobek, S., Tranvik, L.J., Prairie, Y.T., Kortelainen, P. \& Cole J.J. (2006). Patterns and regulation of dissolved organic carbon: An analysis of 7,500 widely distributed lakes. Limnol. Oceanogr., 52, 1208-1219.

Sobotka, D. (1967). Vegetation of the overgrowth zone in lakes that have not natural outflow in the Suwałki region (in Polish). Monogr. Bot., 23, 173-258.

Sokal, R.R. \& Rohlf F.J. (1995). Biometry. New York: W.H. Freeman and Company

Sugier, P. \& Popiołek P. (1999). Differentiation of aquatic and bank vegetation of Długie Lake in the Polesie National Park. Parki Nar. Rez. Przyr., 18, 61-79.

Thienemann, A. (1921). Types of lakes (in German). Naturwissenschaften, 18, 343-346.

Urban, D. (2001). Values of nature and problems of protection in the nature reserve Jezioro Orchowe (Łęczna-Włodawa Lake District). Inż. Ekol., 5, 150-157.

Wiszniewski, J. (1953). Remarks about lake types in Poland (in Polish). Pol. Arch. Hydrobiol., 1, 11-23.

Wojciechowska, W. \& Solis M. (2009). Prokaryotic and eukaryotic algae in the lakes of Łęczna-Włodawa Lake District (in Polish). Lublin: Wydawnictwo KUL.

Wojciechowski, I. (1999). Functioning conditions of peat bog and aquatic-peat bog ecosystems in Poland (in Polish). In S. Radwan \& R. Kornijów (Eds.), Problems of active protection of aquatic and peat bog ecosystems in national parks in Poland (pp. 57-63). Lublin: Wyd. UMCS.

Załuski, T. (1996). Kociołek (in Polish). In M. Rejewski \& P. Bielecki (Eds.), Nature reserves in Toruń Province (pp. 109-111). Toruń: UW w Toruniu, Wydz. Ochr. Środ., Woj. Konserw. Przyr. 